\title{
Struggles Around the Empty Signifier of Freedom: An Interview with Leticia Sabsay
}

\section{Thais de Bakker Castro*}

Leticia Sabsay is a prominent Argentinian academic, based at the London School of Economics, whose work has been exploring pressing issues and questions: how gender and sexuality relate to ideas of freedom, how to define human subjectivity, how to politically resist, among others. In Sabsay's writing, ideas of gender and sexuality cannot be dissociated from our broader political formations and complex processes of becoming subjects in neoliberalism. And our aspirations to evoke political shifts and improvements cannot be separated from a notion of the human as a being with permeable borders, invariably interconnected to others and to a conjunction of experiences - as opposed to the liberal notion of autonomous individuality. I believe she joins theorists like Judith Butler in an attempt to resituate the ontological grounds of our notion of the individual and of our political formations, and she is thus an important reference for feminist and queer efforts to make sense of liberal cooptation, on the one hand, and conservative backlash, on the other. The following is an interview conducted in November of 2018, at the LSE, in which I asked her about her references, her more recent body of work, and her conceptualizations of current tendencies in politics. The interview was lightly edited for clarity.

Thais: Could you start telling me a little bit about your trajectory and your academic interests so that we can have a background?

Sabsay: I've been working in the UK for the last eight years or so, and before that I was in Germany for a little while. Before that, I finished my Ph.D. in Spain and I have a whole past in Argentina, as an Argentinian scholar and teacher as well. In relation to my research, I would say that I am a scholar working at the intersection of political theory, sexuality studies, feminism and queer theory, and what we might understand as cultural studies, from a very profound transdisciplinary point of view. My first major research, out of which I published my first two books, was concerned with sexual politics in Argentina and extending to the South Cone in the post dictatorship period. The question there was how to understand processes of sexual democratization within a broader landscape per-

\footnotetext{
* Pontifícia Universidade Católica do Rio de Janeiro (PUC-Rio), Rio de Janeiro-RJ, Brazil; thais.bakker@gmail. com. ORCID iD 0000-0001-9958-7566.
} 
taining to how democracy was going to be conceived after dictatorship, but also in neoliberal contexts, and how the question of sexual politics emerged there. I focused particularly on the question of sex work; I wrote a lot about sexual citizenship and I would say trans studies, and non-normative gender.

When I moved to Europe, I didn't shift the focus, but in a way I rearticulated my line of inquiry, trying to think what imaginaries of sexual democracy were circulating in the European context, within a completely different political historical moment and geopolitical configuration. So out of that research I did work a lot on sexual citizenship within European contexts and its complicated relationship to the global South, thinking about transnational sexual politics and where the South was imaginarily located within those politics, as always having to catch up with an idea of the North as a 'developed, progressive, and modern' space. My task was to question that, of course. But I also became more and more focused on questions of sexuality in particular, and how the idea of sexual freedom was circulating within that broader political imaginary. And what notion of political subjectivity was presupposed by those politics. Out of that, the book on the political imaginary of sexual freedom came about. After that book, I became more and more interested in questions of embodied contemporary politics within what we could broadly understand as a neoconservative cycle - we can speak more about the difficulty of actually naming the historical present in which we are living.

Thais: Yes. Absolutely.

Sabsay: So it was in that context that questions of vulnerability and resistance came into my enquiry as well.

Thais: You already answered some of the doubts I had. But the first question I wanted to ask is what you think about this... neoliberal tendency? Wendy Brown has recently argued (in 'Neoliberalism's Frankenstein: Authoritarian Freedom in $21^{\text {st }}$ Century "Democracies"” (2018)) that radical right-wing formations have adopted the language of freedom for authoritarian ends, i.e., in the very name of freedom, they oppress those who do not conform to heteropatriarchal norms. And in The Political Imaginary of Sexual Freedom, you write that the 'sexual democratic turn has become a synonym for secularism, democratic values, and a renewed form of modernity that seems to define the boundaries of the Occident' (Sabsay 2016b: 20). How would you combine these two trends? I am wondering if you see any kind of relation between these tendencies how they might be articulated.

Sabsay: Thank you for this question. I have been thinking about this a lot because the book was published in 2016 out of a research I had been carried on since 2011. By the time the book was released, it seemed a little bit out of touch to be talking about processes of democratization, while we were witnessing this turn against democracy. So, for me, it was like, okay, what is going on here? How can we understand this rapid backlash? This is what I have been trying to think in the last two years, for instance in relation to the arguments that Wendy Brown develops in the essay that you mention. First of all, it is fair to say that my work on the political imaginary of sexual freedom was speaking to another historical 
context. It wasn't speaking to the last two or three years. In that context, I was thinking about an idea of sexual freedom that was based on the political tradition of liberalism, and rearticulated in neoliberal terms from the 1990s on in different contexts. An idea of sexual freedom that was then rearticulated around the 2000s, along the lines of 'the war on terror,' in such a way that the idea of democratizing sex, gender and sexualities became foregrounded as a marker of progressiveness, democracy and so on, assuming neo-colonial queues. Such imaginary of sexual freedom became one of the bases for justifying imperialist interventions, especially in the case of the United States. In the case of Europe, it was mobilized for justifying anti-migration discourses, the assumption being that Europe needed to be protected from the influence of 'backward cultures' that were not sufficiently democratic precisely because their gender and sexual politics were pretty conservative.

With the financial crisis of 2008, the division between a more liberal-oriented sexual politics based on human rights, individual rights, and diversity, on the one hand, and on the other hand, more radical sexual politics that were trying to address questions of social justice, basically highlighting that it is not possible to think of freedom as split from equality, became more and more apparent.

This sort of tension within sexual movements has always been there. What I'm saying is that with the heightening of the precarization of broader sectors of the population after the financial crisis, the question about how this affected gender relations and so-called sexual minorities also came to the fore. That was the context in which I was analysing how this idea of sexual freedom was circulating and being rearticulated in one way or another. The idea of freedom that Wendy Brown discusses in that article is an idea of freedom that she describes as anti-democratic, it is 'an authoritarian freedom.' She is analysing the combination of conservative and neoliberal frameworks for coming up with this idea of freedom that circulates, or that has been embraced by right-wing and far-right politicians. So, what can I say in terms of how one idea of freedom relates to the other?

In the first instance, I think that at different historical moments we are both highlighting the fact that freedom in itself, or freedom as an idea, might not necessarily propound the most progressive or emancipatory politics. We can see this in both the neoliberal versions of freedom I was thinking about, and the current conservative right-wing and far-right versions of freedom. The second point that I would make is that another way to think about the work of freedom as an ideal is to think about it as an empty signifier around which different groups struggle, one that might assume very different meanings; there is no ultimate authentic meaning for freedom as a political signifier. This is a question of political struggle. Today we are in a political conjuncture where freedom has become the currency of anti-democratic groups; this complicates the situation for us. For instance, it demands that we ask: What do we mean when we talk about a progressive idea of freedom, or a leftist idea of freedom, or democratic ideas of freedom?

Lastly, I would say that there are two ways of thinking about this shift. We can think that precisely because the neoliberal versions of sexual freedom that were hegemonic in prior moments did not dismantle heteronormative frameworks and structures, as many queer 
theorists pointed out, it has been so easy to question gender and sexual progressive politics, to the extent that they are at such a risk now. That's one way to put it. But one can also say that it is the success of these politics (at least at the level of legislation, in terms of formal rights, what might be deemed as legitimate public discourse, and popular culture) that to some extent explains the emergence of this conservative idea of freedom that Wendy Brown characterizes as a protected private space, one that, in turn, is coupled with corporation's and economic freedom. In a reverse move, conservative far-right or right-wingers argue that this freedom conceived as a protected private space is threatened by social or democratic conceptions of freedom, which they deemed authoritarian. In my view, it is precisely because sexual politics was key to think about democracy in the context of neoliberalism, but also in relation to neo-colonial impulses and associated cultural wars, that these movements are so invested in dismantling any kind of progressive gender and sexual policy. So, it is not just about the fact that these are white hetero patriarchal men; it is not just about reinstating white hetero-patriarchy. It is also about reshaping democracy as a whole, and in particular its relationship to nationalism and geopolitics.

Thais: Yes. It is very interesting that in the beginning you said you thought your book research was a bit out of touch with the changes in context, but I do not think so. I think these are very closely connected tendencies (neoliberal sexual freedom and conservatism).

Sabsay: I think so.

Thais: They speak to each other very closely. What you said about the empty signifier of freedom was very interesting for me. My Master's research was about the Kurdish YPJ, the Kurdish women's militia in Rojava, and I read different narratives about them; the thing that stood out the most for me was that everybody seemed to associate them with freedom (I believe because they are women), but this freedom took very different shapes depending on who was speaking. So, a lot of people thought they were free because they were fighting against ISIS, because they held weapons. But there were also a lot of left-wingers or anarchists who thought they were fighting for freedom because they were dismantling the colonial structures of the nation-state. It seems to me that the struggles around the meanings of freedom are in the very core of our moment, and that they are completely connected to gender and sexuality. And this is also why I think your work on permeability is so interesting, in the sense that you write about in your essay in Vulnerability in Resistance; you defined permeability as 'the capacity to be affected (which might be acknowledged or disavowed)' (Sabsay 2016a: 286). If conservatives take the terms we use and subvert them for their own purposes, I believe this idea of permeability may offer an alternative ground, a different ground for politics, going beyond this struggle. My next question is if you can talk a little more about your concept of permeability. And if you may exemplify for us how the disavowal of permeability has been happening in politics lately.

Sabsay: The idea of permeability works for me as a graphic way of thinking about relationality in a way that has many points in common with Judith Butler's idea of radical relationality - but not necessarily all of them. I don't take the same references as my point of departure, nor do I point to the same focus. For her, it is more of an ethical political 
argument, which does not necessarily work in the same way for me. Butler's idea of radical relationality encompasses material interdependency and the capacity to affect and be affected. With the notion of permeability I tried to specifically develop the dimension of affectability. The main two references that are important for me, for thinking about a subject that is permeable (as opposed to the Enlightenment/post-Enlightenment individualistic conception of subjectivity), have to do with a phenomenological understanding of subjectivity, drawing mainly on Mikhail Bakhtin and Merleau-Ponty. For me, the idea of permeability has to do, on the one hand, with the idea that what we understand as a self-enclosed subject is, in fact, as Merleau-Ponty would say, embodied experience. That is why I am now working specifically on bodies and embodiment, based on the idea that we do not have a body but a lived body, and that lived body is totally relational in the way that it is formed. The lived body works together with the phenomenological idea of intentionality, that is, the body cannot be thought in itself, but rather in relation to the world. I took from Mikhail Bakhtin the idea that we emerge as an ethical self always already responding to an other, and that we are somehow a palimpsest, a metaphor indebted to a consideration of the subject in communicative or discursive terms. This idea of relationality has to do with the idea of being open, incomplete, always in relation to, never being able to give a full account of oneself, as Butler puts it. But it also highlights that we are also plural, incoherent and never able to sustain a univocal voice for ourselves. We have many voices. We are polyphonic in a way. This becomes even clearer when we took into account the psychic dimension of our subjectivity. I am not saying that the self does not exist, and that is where Foucault serves me. We are invested in the idea of the self - 'we ourselves' through narration, address, and many different practices. We are reflexive selves able to narrativize ourselves and, therefore, ethical selves as well. But, if we look at our psychic life, the solidity of the self dissolves quite quickly. The unconscious for me is the emblematic illustration of the permeable subject.

This was specifically important for my critical reflection on sexuality and sexual politics. Most of the sexual politics that are, or were, related to sexual rights, based on sexual orientation and gender identification, rely on an idea of a self-transparent self in control of their desires and able to know what they want. For me, the experience of the sexual - and note that I stopped speaking about sexuality and started speaking about the sexual -, is, as much as the unconscious, a totally permeable and plural experience, where it is not very clear one where one ends and the other begins. The sexual happens in this in-between, not as a property or an attribute of this self-enclosed individual.

Thais: That is why the use of 'the sexual' instead of sexuality.

Sabsay: Yes, exactly. Because I understand sexuality as the dispositive that Foucault talked to us about, and what I am saying in the book is basically that the progressive sexual politics we know today still rely on this idea of sexuality as a dispositive of regulation. Paying attention to the psychic dimension of sexual fantasy was very important for me in the sense that it exceeds the claims enacted by recent and contemporary sexual politics, or the kind of sexual feelings for which we are fighting to have recognised. When based on 
the transparent individual, the understanding of sexual freedom becomes narrower. I was trying to articulate an enhanced vision of the sexual, one that has much in common with the erotic, as theorised by Audre Lorde and foregrounded by other black feminist scholars. Relying on psychoanalytic insights, such as those of the early Freud, Laplanche, and also Butler, allow us to think about the sexual beyond the more restricted idea of sexuality (i.e. as sexual identity). The sexual foregrounds the multiplicity and contradictions of our psychic identifications, desires, and fantasies. Our sexual psychic life is much richer than what those claims are able to express. What might be the implications of articulating this psychic notion of the sexual in political terms? How would then sexual freedom look like?

That was one aspect of my thinking about permeability, sexuality and politics in relation to this idea of relationality; that this is something that has been politically neglected to a great extent. By any liberal conception of democracy, and much more so by neoliberal ones, the trend has been precisely the opposite - imagining that we are not only self-transparent and in control, along the lines of the classic liberal subject that emerges from possessive individualism, but in neoliberal times also shaping ourselves as an enterprise, a self-produced subject that should be self-sufficient and, therefore, also responsible for their own fate without having to rely in any sort of collective force.

Thais: On that note, I am compelled to ask your thoughts about resistance. In this scenario, many of us are feeling especially inclined towards rethinking what are possible forms to resist in an oppressive political climate. Have you been observing any specific cases of resistance based on a politics that acknowledges permeability? How can we resist, well, on those bases of acknowledging permeability?

Sabsay: Well, I think that feminism has been doing that in many different ways throughout its history. I am not saying that I agree with every feminist politics; relationality can be, and indeed has been, conceived in many different ways, and I do not agree with all of them. But, for example, I would say that most of the anti-austerity movements, in one way or another, are staking a demand for the recognition of the social dimension of bounded lives. I am not referring to claims solely linked with the idea that 'we need the welfare state back.' Rather, many anti-austerity and transversal feminist, transfeminist and queer movements are saying that there is a collective mode of being together that the political institutions have to account for, that we cannot see each other as isolated beings that are left to their own fate. Commons activism, I think, has also articulated a vision of being together as the possibility of being only through the being together in a different way. You have different versions of this, but all the movements that demand their right to Common Goods for the wellbeing of everyone, in a way, are challenging individualist approaches to freedom. They are not staking their claims in terms of individual rights. It is about the survival of communities, it is about the things that are common to all, whether it be the struggles against the privatization of resources such as water, or the movements for food sovereignty.

Thais: That is interesting, because I feel that... the elections were just Sunday in Brazil, and we are going to have to figure out ways to articulate ourselves in face of this new context, 
which we do not know how it is going to develop. There is a slogan going viral in Brazil which says something like 'nobody should drop anyone's hand,' and maybe it reflects this logic of being together.

Sabsay: That is a great example. Yesterday, I was at a Roundtable on Brexit, on migration, and someone was speaking about the PAH (Plataforma de los Afectados por la Hipoteca) in Barcelona, the social movement that Ada Colau, the now mayor of Barcelona was president of. The direct actions of the Plataforma were very much based on the principle that nobody should be evicted from their home, and the practical translation of this principle has been 'you help me, I help you' in bodily resisting the evictions. This is a horizontal movement of civil disobedience, by which those who have not being able to pay their loans after the financial crisis and were being evicted started to build networks to show up at any eviction procedure to stop the eviction. Any person that the network helped would be then committed to becoming part of the group that would stop the eviction of someone else.

This movement is not based on identification or identity, but sustained by a very concrete, embodied practice of solidarity that for me also speaks to the idea of relationality and permeability. It is a movement that by their actions says: 'I do not care who you are, or from which country you came; the police should not put you on the street, and so we come here and we stop this eviction.' For me, this speaks to the idea of embodied relationality.

Thais: That is very interesting. The feeling many of us have is that plenty of options are getting taken away; the educational and health systems are being dismantled, just like rights and measures in relation to gender and sexuality. There is a very strong dismantling project going on. So, the grounds some of us base our identities on, our visions of our own futures, are being shaken. So perhaps we are attempting to take steps back to acknowledge that community is really the only solid basis for life, or maybe living...

Sabsay: Yes, but there is a risk in such an approach. What I do not like with an unproblematized notion of community is that it slips very easily into communitarian thought.

Thais: Community is also something that can mean many things.

Sabsay: Exactly. I understand your point and I agree that thinking in terms of community could exceed political formations based on identification, on 'you are like me, you are not like me' kind of bordering between self and others. But we need to make sure that those communities do not end propounding some expanded notion of identity as well, because then, you know, exclusion goes on.

Thais: Of course. Well, I also wanted to ask you about your idea of political imaginaries, because I feel that it relates to lots of different thoughts and concepts like the dispositives you've been talking about. So I want to ask if you could discuss these ideas of imaginaries a bit more, and if they are still limiting us in any sense. How is it possible to rebuild or displace imaginaries in any way, also going towards our discussion about resistance? Do you think knowledge production is helpful? How do these imaginaries relate to our psychic investments? 
Sabsay: I understand political imaginaries in psychoanalytic terms, taking into account their psychosocial dynamics. I take as a point of departure the idea that there is no political imaginary that could work without the psychic investment of the subjects in it. In turn, this idea of the psychic investment allows me to account for two different aspects regarding how political imaginaries work. Firstly, my conception highlights that our psychic political imaginaries might not be quite the same or similar to what political discourses explicitly articulate. For example, that we represent ourselves as democratic, or that we believe that we are not sexist anymore, does not mean that we are not psychically very much invested in sexist formations, and/or homophobic and transphobic structures. When we do a symptomatic reading of the political imaginary, we can see the dissonance between critique - typical of post-essentialist and reflexive societies -, and how we work as a society. Secondly, the psychic level is important because it is also at this level that we resist norms as well - unconscious life after all operates together with our psychic resistance to imposed social norms and boundaries. So it is there that we might also find the possibility of pushing, expanding, transforming these social limits. The political imaginary cannot be transformed by will, nor can critical discourses can effectively do all the work. Other manifestations more related to the sensible, and to the possibility of imagining differently, of opening up worlds have to be in place. Hence the importance of art, fiction, and cultural forms of activism.

Thais: I think you have answered most of my doubts. Just one last question: I believe that psychic investments are a very necessary framework for thinking about politics in contemporary times, when attachments to populist, hypermasculine leaders are surpassing any kind of compromise with the 'truth', which seems to be a category already overcome. How do you think far-right political strategies of mobilization, like those intermediated by Cambridge Analytica, relate to our psychic investments? Does it also relate to your idea of permeability?

Sabsay: Let us say the following: that there is an unconscious level at which discourses work. This is something that we always knew, and that politicians always knew, and that agencies, political marketing, political branding, always knew. Nobody that really dedicates themselves to politics relies on the idea that we are rational subjects that only understand arguments; this is not how politics works. This is common sense for anyone who has worked in marketing or in politics. These kinds of psychometrics can be used for many different reasons and purposes. You have the example of Cambridge Analytica and how messages are catered to specific targets relying on these psychological profiles. Institutions rely on the same presumptions for measuring, for example, unconscious bias. When these kinds of studies work as a way of disavowing the need to address structural racism in institutions, they might be understood as progressive in certain ways, but they tend to individualise a structural problem. These are other forms of psychological profiling. I do not agree with the behavioural theoretical basis of these studies. The idea of psychological profiling is disgusting. It also reminds me of the psychological theories of the 1950s, on which advertising was relying for the development of subliminal communication, and social engineering. And it is not surprising to me that today we have this kind of extreme 
version of those fantasies of social engineering, bringing the echoes of the authoritarian personality theorised by Adorno and Horkheimer. Not surprising that these kinds of knowledge are being used.

Thais: Yes, I get the feeling that they are trying to detect 'what do you need'? 'What do you lack'? And then they give us a figure for us to project something onto, then this person's going to fill voids, or provide something. It seems to be working.

Sabsay: Yes, I agree, that is a very important point. Perhaps, one difference between the fantasies of social engineering of the 1950s and these current kinds of psychometrics is that they fit well with the argument Wendy Brown makes in the article we have mentioned about repressive desublimation and the emergence of a subject who is pleasure-oriented and co-opted by capitalism through the logic of consumption. In effect, psychometrics work in tandem with the logic of consumption.

Thais: Yes, that is perfect.

\section{References}

Brown, Wendy. 2018. 'Neoliberalism's Frankenstein: Authoritarian Freedom in the $21^{\text {st }}$ Century "Democracies." Critical Times 1 (1): 60-79.

Sabsay, Leticia. 2016a. 'Permeable Bodies: Vulnerability, Affective Power, Hegemony' In Judith Butler, Zeynep Gambetti and Leticia Sabsay (eds), Vulnerability in Resistance. London: Duke University Press.

Sabsay, Leticia. 2016b. The Political Imaginary of Sexual Freedom: Subjectivity and Power in the New Sexual Democratic Turn. London: Palgrave Macmillan.

\section{About the Author}

Thais de Bakker Castro is a PhD Candidate at the International Relations Institute of the Pontifical Catholic University of Rio de Janeiro (IRI-PUC-Rio). She has a Master's Degree from the same institution, in which she researched gendered readings of freedom found in narratives about the Kurdish YPJ (Women's Protection Units), and a Master's Degree in Philosophy from the Federal University of Rio de Janeiro (PPGF-UFRJ), in which she researched possible theoretical understandings of the nation-state through Judith Butler's philosophy. She is currently conducting an interdisciplinary research project on political visualizations of global futures, combining themes such as political myths, metaphors, imagination and imaginaries.

Received on 15 May 2019, and approved for publication on 16 May 2019.

\section{(cc) BY-NC} https://creativecommons.org/licenses/by-nc/4.0/ 